\title{
Microstructure and Oxidation Behavior of Metal V Films Deposited by Magnetron Sputtering
}

\author{
Song Zhang ${ }^{1} \mathbb{D}$, Tingting Wang ${ }^{1}$, Ziyu Zhang ${ }^{1} \mathbb{D}$, Jun $\mathrm{Li}^{2}{ }^{2}$, Rong Tu ${ }^{1, *}$, Qiang Shen ${ }^{1}$, \\ Chuanbin Wang ${ }^{1}$, Guoqiang Luo ${ }^{1}$ and Lianmeng Zhang ${ }^{1}$ \\ 1 State Key Laboratory of Advanced Technology for Materials Synthesis and Processing, \\ Wuhan University of Technology, 122 Luoshi Road, Wuhan 430070, China; superkobe0104@gmail.com (S.Z.); \\ 18202767268@163.com (T.W.); zhangziyu1108@foxmail.com (Z.Z.); sqqf@263.net (Q.S.); \\ wangcb@whut.edu.cn (C.W.); luoguoqiang1980@sina.com (G.L.); LMZhang@whut.edu.cn (L.Z.) \\ 2 National Key Laboratory for Shock Wave and Detonation Physics, Institute of Fluid Physics, \\ P.O. Box 919-102, Mianyang 621900, China; lijun102@caep.cn \\ * Correspondence: turong@whut.edu.cn; Tel.: +86-27-87499449
}

Received: 24 December 2018; Accepted: 28 January 2019; Published: 30 January 2019

\begin{abstract}
Direct-current magnetron sputtering (DCMS) was applied to prepare vanadium (V) films on Si substrate. The influence of substrate temperature $\left(T_{\mathrm{s}}\right)$ and target-substrate distance $\left(D_{\mathrm{t}-\mathrm{s}}\right)$ on phase structure and surface morphology of $\mathrm{V}$ films were investigated by $\mathrm{X}$-ray diffraction (XRD), scanning electron microscopy (SEM), atomic force microscope (AFM) and transmission electron microscopy (TEM). The results show that the crystallinity of the $\mathrm{V}$ films increases with increasing $T_{\mathrm{s}}$ and decreasing $D_{\mathrm{t}-\mathrm{s}}$. The film deposited at $T_{\mathrm{s}}=400^{\circ} \mathrm{C}$ and $D_{\mathrm{t}-\mathrm{s}}=60 \mathrm{~mm}$ exhibits the best crystallinity and $<111>$ preferred orientation with a regular tetrahedral surface morphology. Oxidation behavior of the V thin films has also been studied by X-ray photoelectron spectroscopy (XPS).
\end{abstract}

Keywords: Vanadium films; magnetron sputtering; substrate temperature $\left(T_{\mathrm{s}}\right)$; target-substrate distance $\left(D_{\mathrm{t}-\mathrm{s}}\right)$; microstructure; oxidation behavior

\section{Introduction}

Vanadium (V), a strategic rare metal material, has several excellent physical and chemical properties, when compared with other metals; these include high hardness, high melting point, good thermal and electrical conductivity, and good corrosion resistance. Initially, it was used as an alloying element to increase the strength of vanadium high-carbon steel alloys [1]. In recent years, metallic $\mathrm{V}$ thin films have attracted more attention and have been used on objects to achieve isolation from the surrounding environment, considering their advantages of high temperature resistance, hydrochloric acid, and sulfuric resistance [2]. In addition, hybrid nanocomposites are a rapidly growing field of science in pursuit of novel materials with tailored functionality and improved properties [3]. It might be possible to fabricate thin film nano-patterns for optical, electrical or sensing applications using this material [3,4]. There has been extensive research on bulk vanadium [5-8]. In contrast, very little work has been reported on $\mathrm{V}$ thin films, whose properties may differ from those of bulk because of the small size in the direction of thickness and the interrupted continuity by the presence of surfaces and interfaces. Li et al. [9] deposited $\mathrm{V}$ films on aluminum alloy substrates using high power pulse magnetron sputtering (HPPMS) and found that the $D_{\mathrm{t}-\mathrm{s}}$ has a critical effect on surface morphology, microstructure, deposition rate, and corrosion resistance. Wei et al. [10] successfully produced fully dense, nano-structured $\mathrm{V}$ thin films using a two-step consolidation method. They concluded that the grain size of nano-structured $\mathrm{V}$ thin films is in the order of $100 \mathrm{~nm}$, identified by X-ray diffraction and transmission electron microscopy. They measured the mechanical properties of nano-structured $\mathrm{V}$ thin 
films consolidated at $600{ }^{\circ} \mathrm{C}$ using both quasi-static and dynamic compression tests and reported that the Vickers hardness is $6.0 \mathrm{GPa}$ [10]. Vanadium is harder than most metals, but oxidizes even in ambient air. Mamun et al. [1] fabricated V thin films with different thicknesses on Si substrates by magnetron sputtering, and investigated the natural oxidation behavior and mechanical properties of the deposits. It was reported that by measuring the $30 \%$ depth of the film thickness and eliminating the influence of the substrate on the film properties, the hardness of oxidized films depicted less variation than un-oxidized films. This result shows that oxidation of the V film may affect its mechanical properties. Previous researchers have focused more on the mechanical properties and corrosion resistance of $\mathrm{V}$ films. However, few reports have systematically studied the structure and morphology of V films and the relationship between structure and oxidation behavior.

Methods such as evaporation, molecular beam epitaxy, sputtering, and pulsed laser deposition have been used to prepare V films [11-14]. Among them, the sputtering method is widely used because of its good adhesion between the film and substrate, controllable film thickness, high repeatability, and high purity of the prepared film.

In this work, the DC magnetron sputtering (DCMS) technique was adopted to prepare the V films. The effects of substrate temperature $\left(T_{\mathrm{s}}\right)$ and target-substrate distance $\left(D_{\mathrm{t}-\mathrm{s}}\right)$ on microstructure and surface morphology of the $\mathrm{V}$ films were investigated by various testing methods. We then discussed the relationship between structure and natural oxidation behavior.

\section{Materials and Methods}

The V films were deposited by DC magnetron sputtering on Si (100). After 20-min ultra-sonic bath in acetone, the Si substrate $\left(10 \times 10 \times 0.5 \mathrm{~mm}^{3}\right)$ was fixed on the substrate holder. As the sputtering source material, a V-metal target (purity: 99.9\%) with a diameter of 2 inches was used. The vacuum chamber was evacuated to a base pressure lower than $9.0 \times 10^{-4} \mathrm{~Pa}$. Argon gas was introduced into the chamber to maintain a pressure of $0.5 \mathrm{~Pa}$. The sputtering power was fixed at $100 \mathrm{~W}$. Before starting the deposition, the $\mathrm{V}$ target was pre-sputtered for $5 \mathrm{mins}$ to remove contamination from the target surface. The substrate temperature $\left(T_{\mathrm{s}}\right)$ varied from $25{ }^{\circ} \mathrm{C}$ to $400{ }^{\circ} \mathrm{C}$. The target-substrate distance $\left(D_{\mathrm{t}-\mathrm{s}}\right)$ changed from $60 \mathrm{~mm}$ to $100 \mathrm{~mm}$. The sputtering time was 60 mins.

Structural properties of the films were analyzed using X-ray diffraction with a multipurpose platform attachment (XRD, Ultima III, Rigaku, Tokyo, Japan) with CuK $\alpha$ source at $40 \mathrm{kV}$ and $40 \mathrm{~mA}$. Microstructural observation of the deposited films was carried out using transmission electron microscopy (TEM, JEM-3010, JEOL Ltd., Tokyo, Japan) at an accelerating voltage of $200 \mathrm{kV}$. The chemical state of elements in the films was analyzed using X-ray photoelectron spectroscopy (XPS, ESCALAB 250Xi, Thermo Fischer, Waltham, MA, USA). Surface morphology of the films were studied using field emission scanning electron microscopy (FESEM, Quanta-250, FEI, Houston, TX, USA) at an accelerating voltage of $25 \mathrm{kV}$ and atomic force microscope (AFM, Multimode 8, Bruker, Karlsruhe, Germany).

\section{Results}

Figure 1 shows the XRD patterns of V films deposited on Si (100) substrate at $D_{\mathrm{t}-\mathrm{s}}=60 \mathrm{~mm}$ with different $T_{\mathrm{S}}$. At $T_{\mathrm{S}}$ of 25 and $100{ }^{\circ} \mathrm{C}$, the phase of as-deposited films is amorphous, whereas at $T_{\mathrm{S}}$ of $200{ }^{\circ} \mathrm{C}$, only $\mathrm{V}(111)$ and $\mathrm{Si}(100)$ peaks could be observed, indicating that the deposited $\mathrm{V}$ film is totally $<111>$-orientation, which means that the preferred is $<111>$-orientation. The relative intensity of the $\mathrm{V}$ (111) films increases on increasing $T_{\mathrm{s}}$ from $200{ }^{\circ} \mathrm{C}$ to $400{ }^{\circ} \mathrm{C}$. The results indicate that high substrate temperatures result in better crystallinity of the films. It is generally understood that the deposited atoms on the substrate have more opportunity to move around on the substrate, forming larger crystallites in the film, when a higher $T_{\mathrm{s}}$ is applied [15]. 


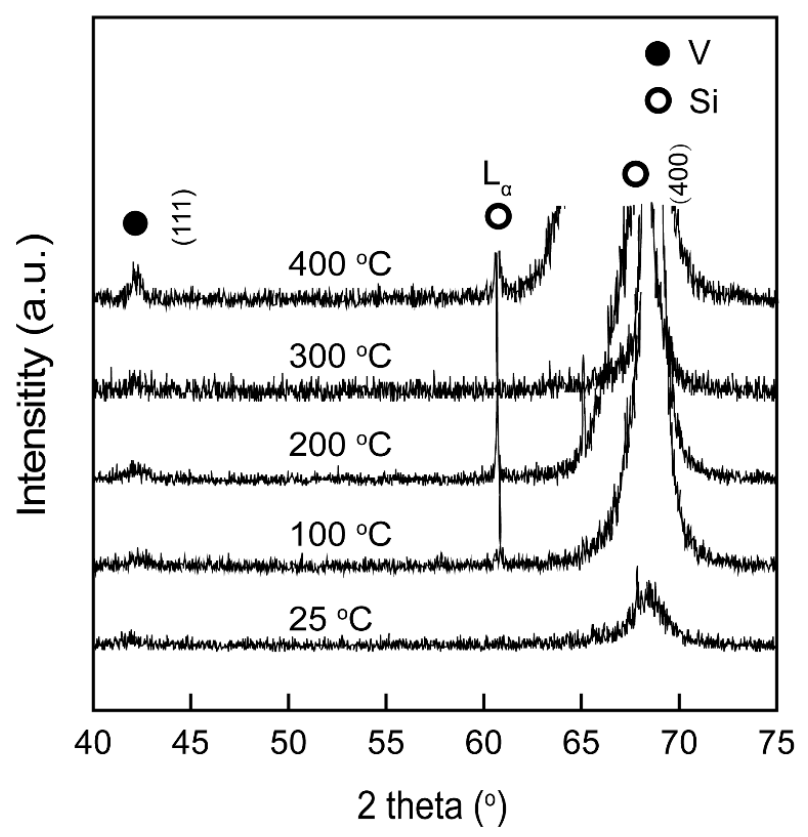

Figure 1. XRD patterns of $\mathrm{V}$ films deposited on $\mathrm{Si}(100)$ at $D_{\mathrm{t}-\mathrm{s}}=60 \mathrm{~mm}$ with different $T_{\mathrm{s}}$.

The SEM images in Figure 2 represents the surface morphologies of V films deposited on Si (100) substrate at $D_{\mathrm{t}-\mathrm{s}}=60 \mathrm{~mm}$ with different $T_{\mathrm{s}}$. The surface of the $\mathrm{V}$ film prepared at $25^{\circ} \mathrm{C}$ exhibited features similar to a cauliflower. As $T_{\mathrm{s}}$ increased to $100^{\circ} \mathrm{C}$, the surface of the $\mathrm{V}$ films gradually flattens and particle size of $\mathrm{V}$ films gradually increases. With further increase of $T_{\mathrm{S}}$, the surface morphologies of $\mathrm{V}$ films evolves from a sphere in Figure $2 \mathrm{a}, \mathrm{b}$ to a polyhedron in Figure $2 \mathrm{c}, \mathrm{d}$, and then to a triangular pyramid in Figure 2e. It is worth mentioning that the unique triangular pyramid-like morphology of the $\mathrm{V}$ film represents a preferred <111>-orientation [16-18], corresponding to the XRD results in Figure 1.
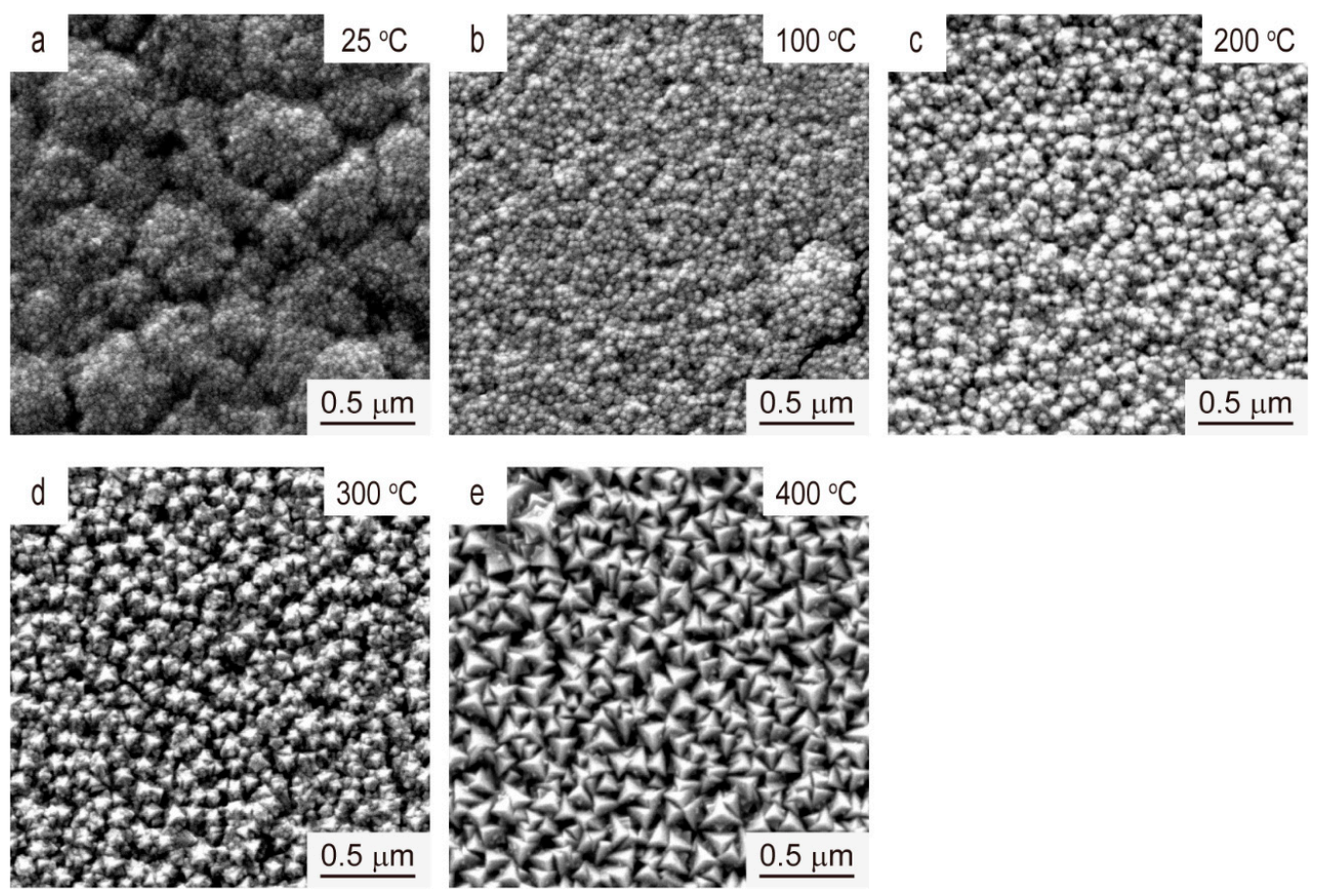

Figure 2. SEM images of the $\mathrm{V}$ films deposited on $\mathrm{Si}(100)$ at $D_{\mathrm{t}-\mathrm{s}}=60 \mathrm{~mm}, \mathrm{~T}_{\mathrm{s}}=(\mathbf{a}) 25^{\circ} \mathrm{C},(\mathbf{b}) 100{ }^{\circ} \mathrm{C}$, (c) $200{ }^{\circ} \mathrm{C}$, (d) $300^{\circ} \mathrm{C}$, and (e) $400{ }^{\circ} \mathrm{C}$. 
Figure 3 shows atomic force micrograph images of the $\mathrm{V}$ films deposited at $D_{\mathrm{t}-\mathrm{s}}=60 \mathrm{~mm}$ with different $T_{\mathrm{s}}$. It was found that the surface particles of the films gradually became larger and the uniformity of the films gradually increased, which was consistent with the SEM results. In addition, the effect of substrate temperatures $\left(T_{\mathrm{s}}\right)$ on the mean surface roughness $\left(R_{\mathrm{a}}\right)$ of the $\mathrm{V}$ films was shown in Figure 4. It was found that $R_{\mathrm{a}}$ decreased first and then increased on increasing $T_{\mathrm{s}}$. The decrease in $R_{\mathrm{a}}$ is caused by the fact that high $T_{\mathrm{s}}$ promotes the arrival of $\mathrm{V}$ atoms in the desired location due to enhanced diffusion movement, resulting in a smoother surface when $T_{\mathrm{s}}$ is below $100{ }^{\circ} \mathrm{C}$ [19]. However, when $T_{\mathrm{s}}$ exceeds $100{ }^{\circ} \mathrm{C}$, the increased particle size of the surface leads to an increase in the roughness of the $\mathrm{V}$ films [20].
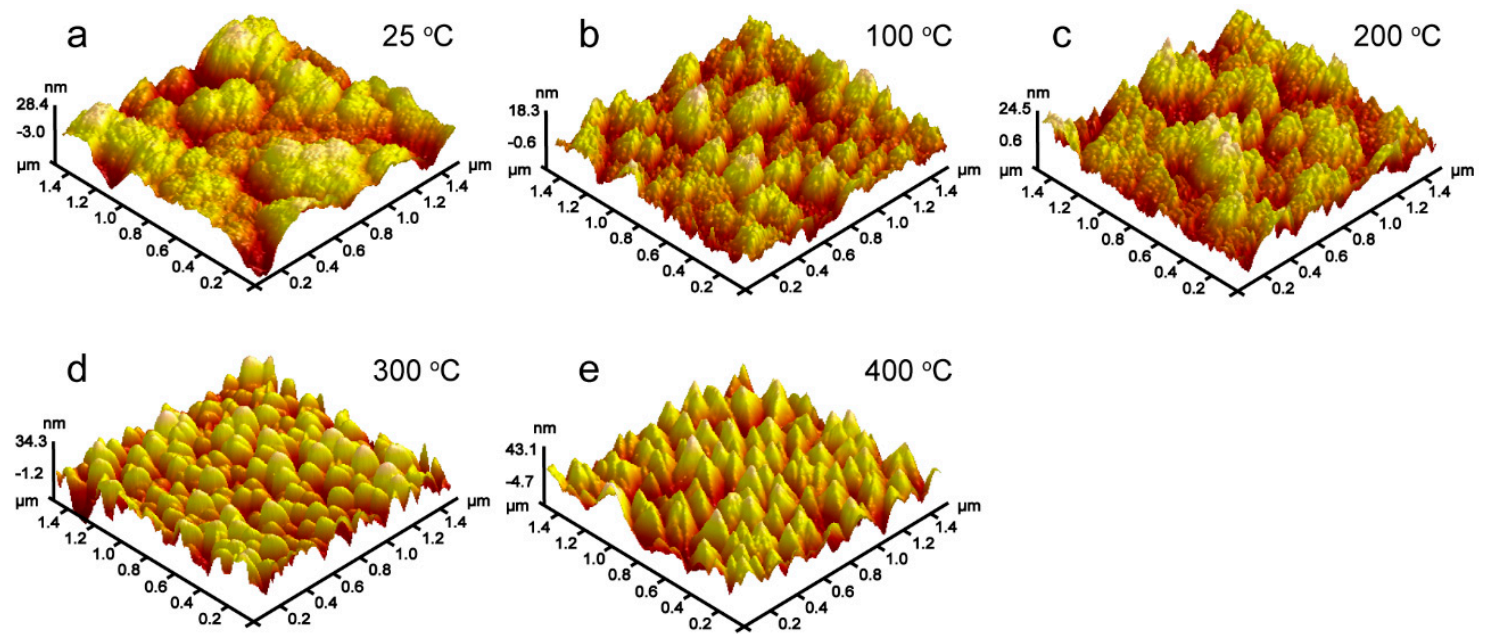

Figure 3. AFM results of $\mathrm{V}$ films deposited on $\mathrm{Si}(100)$ at $D_{\mathrm{t}-\mathrm{s}}=60 \mathrm{~mm}, T_{\mathrm{s}}=(\mathbf{a}) 25^{\circ} \mathrm{C},(\mathbf{b}) 100{ }^{\circ} \mathrm{C}$, (c) $200{ }^{\circ} \mathrm{C}$, (d) $300{ }^{\circ} \mathrm{C}$, and (e) $400^{\circ} \mathrm{C}$.

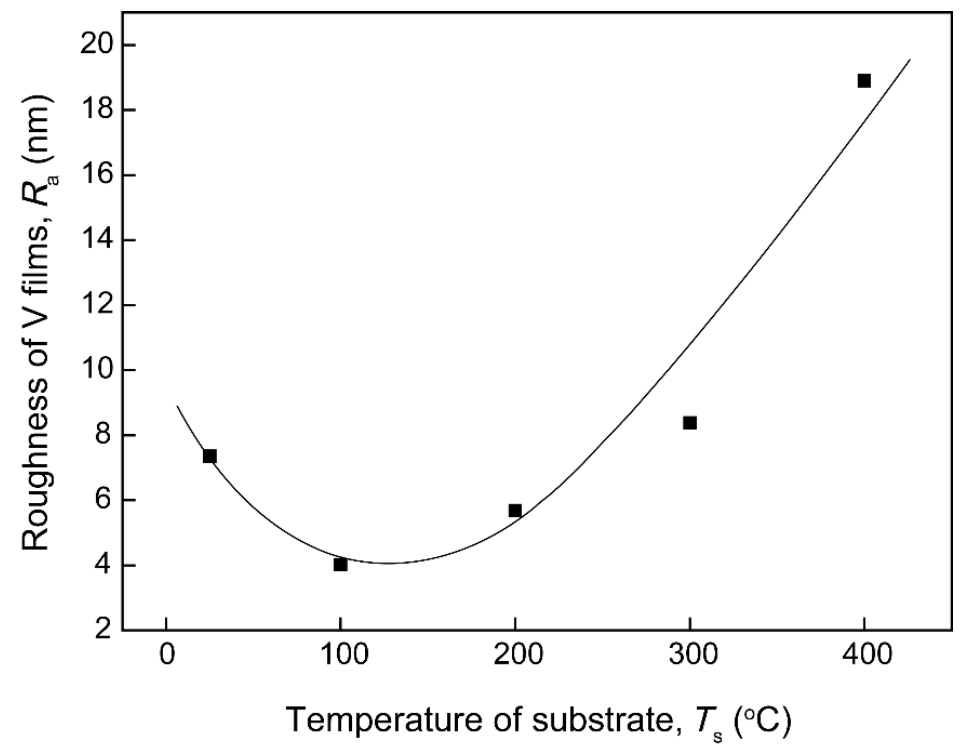

Figure 4. Effects of substrate temperatures $\left(T_{\mathrm{s}}\right)$ on the roughness $\left(R_{\mathrm{a}}\right)$ of V films on Si (100).

The XRD patterns of $\mathrm{V}$ films deposited at $T_{\mathrm{s}}=400{ }^{\circ} \mathrm{C}$ with different $D_{\mathrm{t}-\mathrm{s}}$ were shown in Figure 5 . The relative intensities of $\mathrm{V}$ (111) peaks decreased with increasing the $D_{\mathrm{t}-\mathrm{s}}$, indicating that the crystallinity of the film was deteriorated. The average free path of the particles in the vacuum chamber is constant at a certain working pressure and sputtering power. When the substrate is kept closer to the target, the particles have higher energy since they undergo less number of collisions. Hence, the particles are more mobile on the substrate surface, leading to good crystallinity of the film. 
When $D_{\mathrm{t}-\mathrm{s}}$ is increased, the sputtered particles undergo more collisions and hence will have a lower mobility and this results in less crystalline films [21].

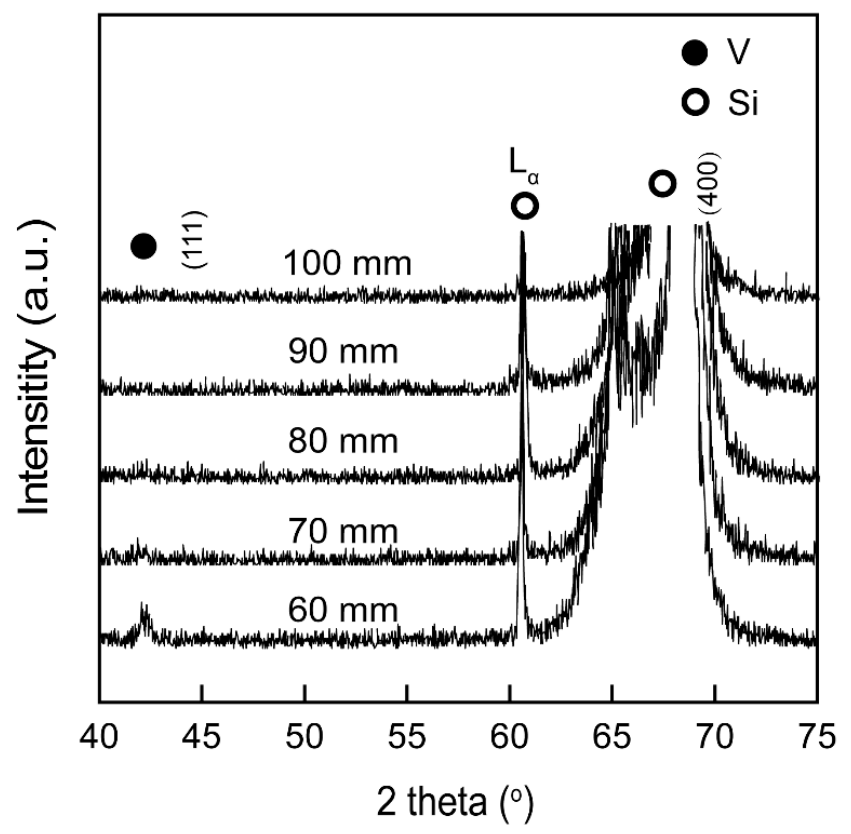

Figure 5. XRD patterns of $\mathrm{V}$ films deposited on $\mathrm{Si}(100)$ at $T_{\mathrm{s}}=400{ }^{\circ} \mathrm{C}$ with different $D_{\mathrm{t}-\mathrm{s}}$.

Figure 6 represents the surface morphologies of $\mathrm{V}$ films deposited on the $\mathrm{Si}(100)$ substrate at $T_{\mathrm{s}}=400{ }^{\circ} \mathrm{C}$ with different $D_{\mathrm{t}-\mathrm{s}}$. The particle size of the $\mathrm{V}$ films decreases on increasing $D_{\mathrm{t}-\mathrm{s}}$. The variation of surface morphologies is related to the reduced crystallinity and preferred orientation of the V films, in consistent with the XRD data in Figure 5.
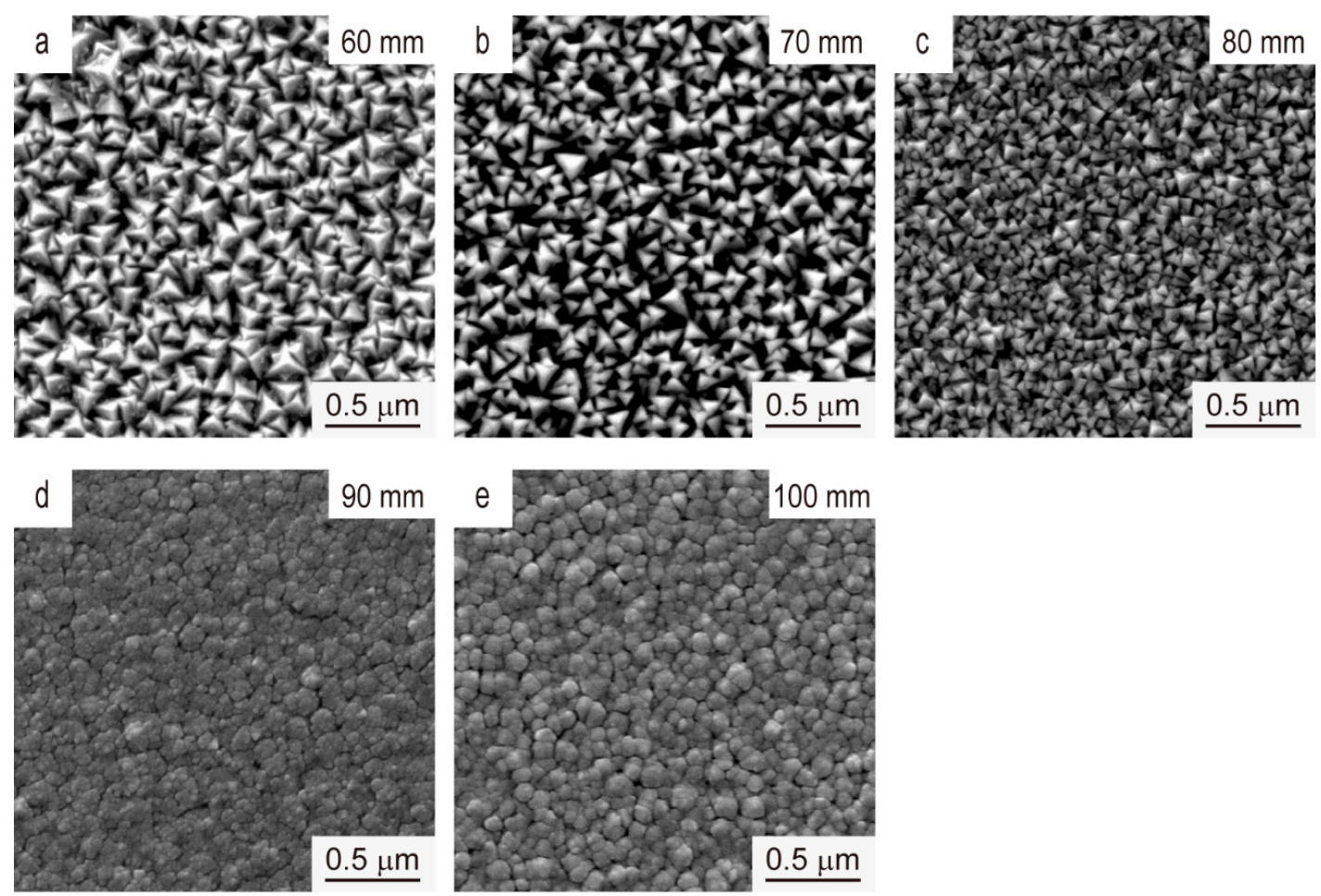

Figure 6. SEM images of the V films deposited on Si (100) at $T_{\mathrm{s}}=400{ }^{\circ} \mathrm{C}, D_{\mathrm{t}-\mathrm{s}}=(\mathbf{a}) 60 \mathrm{~mm},(\mathbf{b}) 70 \mathrm{~mm}$, (c) $80 \mathrm{~mm}$, (d) $90 \mathrm{~mm}$, and (e) $100 \mathrm{~mm}$. 
The AFM images of $\mathrm{V}$ films deposited on $\mathrm{Si}(100)$ substrate at $T_{\mathrm{s}}=400{ }^{\circ} \mathrm{C}$ with different $D_{\mathrm{t}-\mathrm{s}}$ are shown in Figure 7. The size of the triangular pyramid-shaped particles gradually becomes smaller as $D_{\mathrm{t}-\mathrm{s}}$ increases. The particles on the surface of the $\mathrm{V}$ film prepared above $80 \mathrm{~mm}$ gradually transform into a cone shape. The effects of target-substrate distances $\left(D_{\mathrm{t}-\mathrm{s}}\right)$ on the roughness $\left(R_{\mathrm{a}}\right)$ of $\mathrm{V}$ films deposited on $\mathrm{Si}$ (100) substrate were investigated in Figure 8. We can draw a conclusion that the $R_{\mathrm{a}}$ of $\mathrm{V}$ films decreases with an increase in $D_{\mathrm{t}-\mathrm{s}}$. The decreased $R_{\mathrm{a}}$ may be attributed to the decreased particle size caused by the weakened preferred orientation and competitive growth of grains.
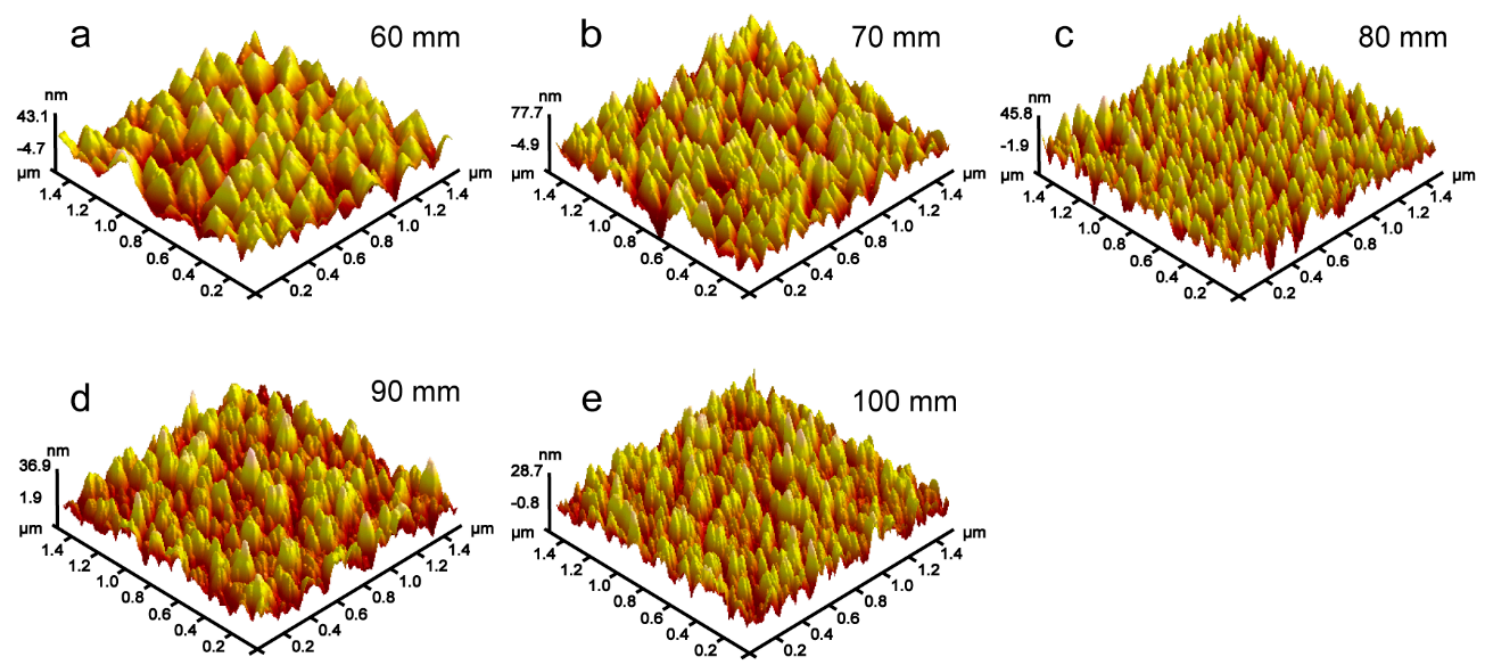

Figure 7. AFM results of $\mathrm{V}$ films deposited on $\mathrm{Si}(100)$ at $T_{\mathrm{s}}=400^{\circ} \mathrm{C}, D_{\mathrm{t}-\mathrm{s}}=(\mathbf{a}) 60 \mathrm{~mm},(\mathbf{b}) 70 \mathrm{~mm}$, (c) $80 \mathrm{~mm},(\mathbf{d}) 90 \mathrm{~mm}$, and (e) $100 \mathrm{~mm}$.

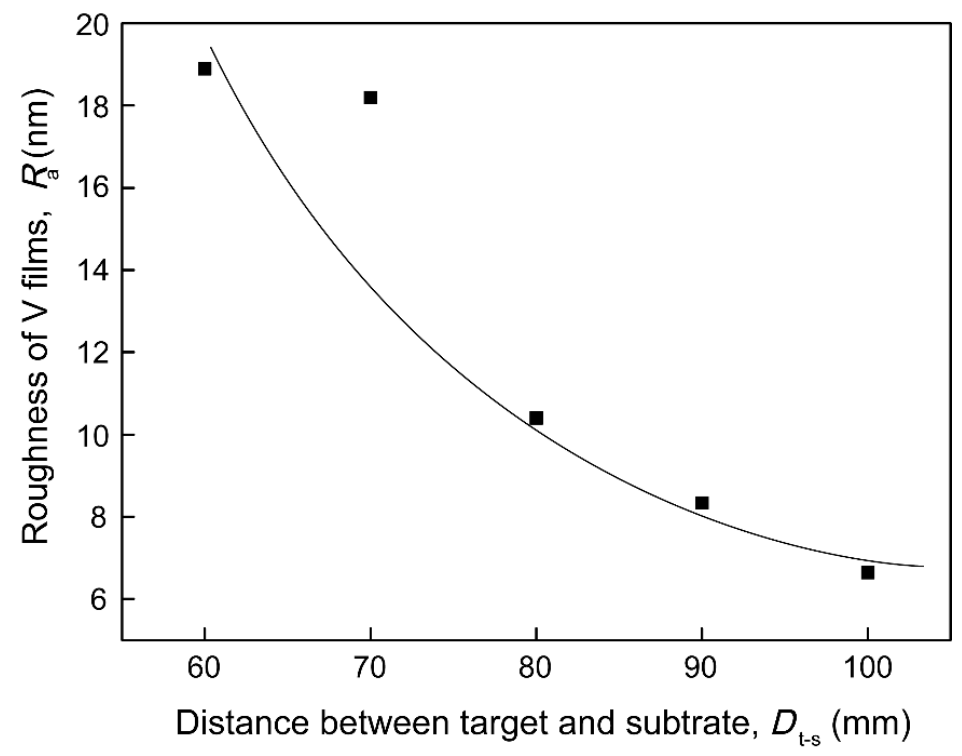

Figure 8. Effects of target-substrate distances $\left(D_{\mathrm{t}-\mathrm{s}}\right)$ on the roughness $\left(R_{\mathrm{a}}\right)$ of $\mathrm{V}$ films on $\mathrm{Si}(100)$.

Figure 9 shows the surface and cross-sectional SEM images of the V film on Si (100) deposited at $T_{\mathrm{s}}=400{ }^{\circ} \mathrm{C}$ and $D_{\mathrm{t}-\mathrm{s}}=60 \mathrm{~mm}$. The morphology of the as-fabricated $\mathrm{V}$ film is a triangular pyramid containing the slowest-growing $\{111\}$ planes, and with the fastest growing <111>-direction [22]. The cross-section of an as-fabricated V film shows that the film exhibits a columnar grain structure. 


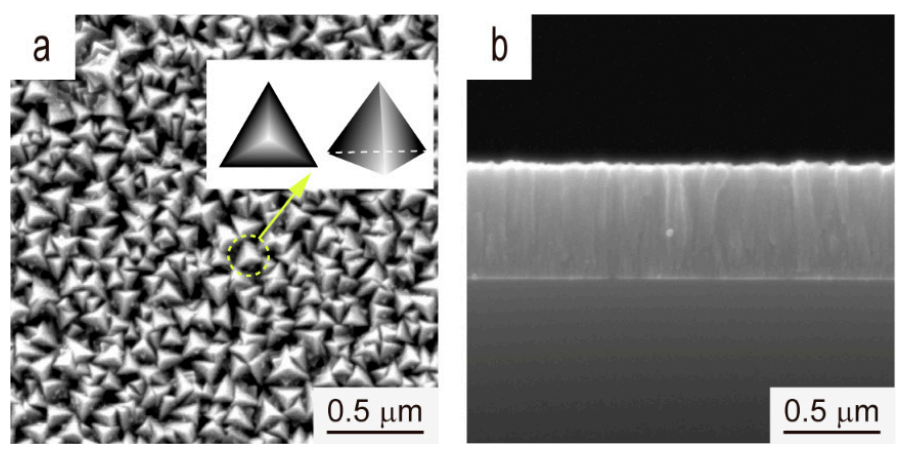

Figure 9. (a) Surface and (b) cross-sectional SEM images of the $\mathrm{V}$ film deposited on $\mathrm{Si}(100)$ at $T_{\mathrm{S}}=400{ }^{\circ} \mathrm{C}$ and $D_{\mathrm{t}-\mathrm{s}}=60 \mathrm{~mm}$.

Transmission electron microscopy (TEM) was used to further investigate the structure of the V film on $\mathrm{Si}$ (100) deposited at $T_{\mathrm{s}}=400{ }^{\circ} \mathrm{C}$ and $D_{\mathrm{t}-\mathrm{s}}=60 \mathrm{~mm}$ in Figure 10. Figure 10a illustrates the cross-sectional TEM images of the $\mathrm{V}$ film deposited at $T_{\mathrm{s}}=400^{\circ} \mathrm{C}$ and $D_{\mathrm{t}-\mathrm{s}}=60 \mathrm{~mm}$. The cross section exhibits a columnar structure with a flat top. The selective area electron diffraction (SAED) pattern of the yellow square area inserted in Figure 10a demonstrated the presence of metallic $\mathrm{V}$ nanoparticles in the $\mathrm{V}$ films. The texture of $\mathrm{V}$ was a face-centered cubic (FCC) structure, indexed as (111), (200) and (220). The TEM image in Figure $10 \mathrm{~b}$ shows that the $\mathrm{V}$ film exhibits single crystal features in a small range. Figure 10c,d are HRTEM images of region I and II, respectively. The lattice fringe spacing of $0.219 \mathrm{~nm}$ is related to (111) plane of metallic vanadium. The insets in Figure 10c,d were a Fast Fourier Transform (FFT) of the corresponding HRTEM images, which reveals the (slightly tilted) hexagonal symmetry of the lattice of metallic vanadium.
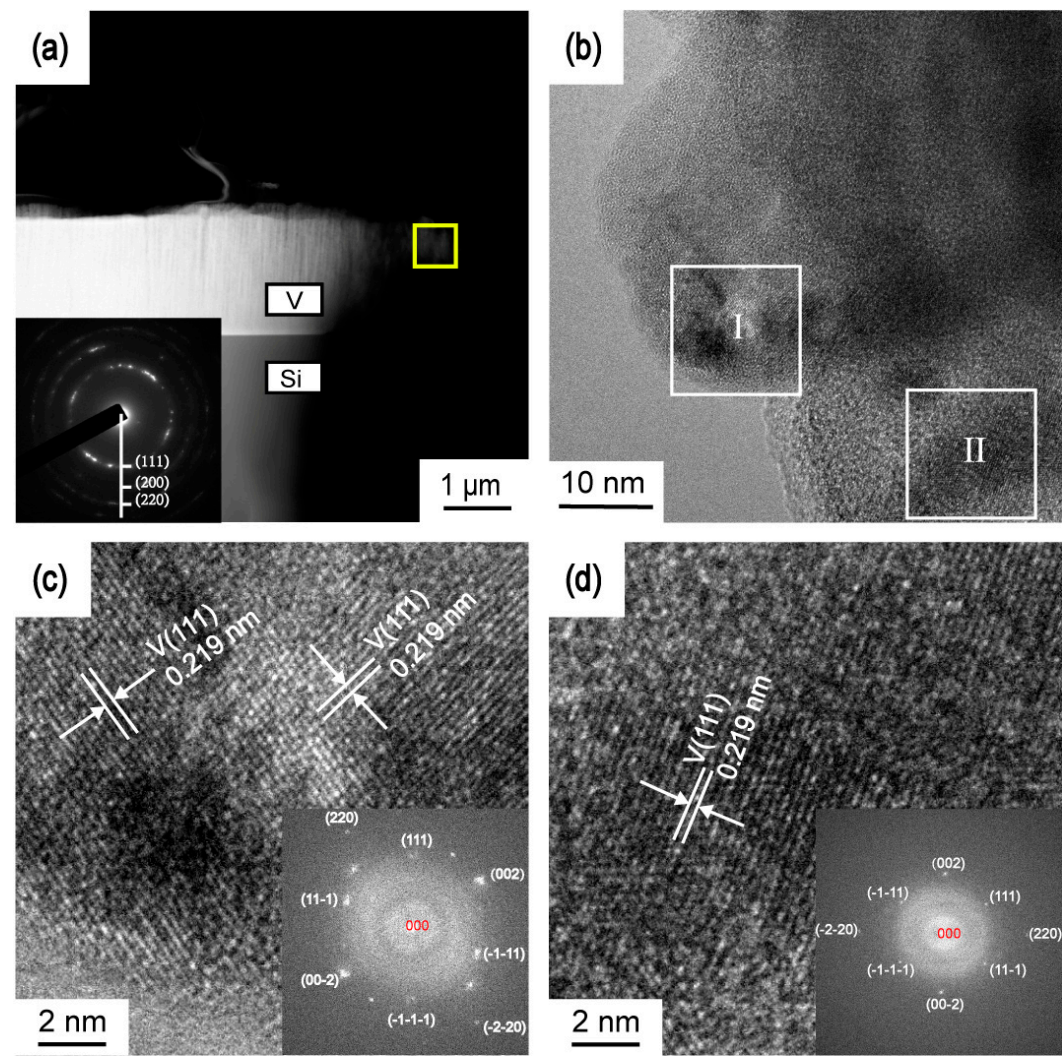

Figure 10. (a) Cross-sectional TEM image of the V film deposited on $\mathrm{Si}$ (100) at $T_{\mathrm{S}}=400{ }^{\circ} \mathrm{C}$ and $D_{\mathrm{t}-\mathrm{s}}=60 \mathrm{~mm}$ and SAED pattern of the yellow square area in insert, (b) TEM image of the yellow square area in (a), (c) HRTEM image and Fast Fourier Transform (FFT) of region I, (d) HRTEM image and Fast Fourier Transform (FFT) of region II. 
XPS analysis was performed to study the composition of natural oxide layer of the $\mathrm{V}$ films placed in air for 1 month. XPS spectra of V 2p of the V films deposited at different parameters shown in Figures 11 and 12 indicates the existence of multivalent vanadium ions $\left(\mathrm{V}^{2+}, \mathrm{V}^{3+}, \mathrm{V}^{4+}, \mathrm{V}^{5+}\right)$. XPS fitting results for the $\mathrm{V} 2 \mathrm{p}_{3 / 2}$ peaks of vanadium oxides reported in this study referred to a form listed by $\mathrm{E}$. Hryha [23]. It could be seen roughly that the XPS results confirm the presence of a natural oxidation layer of $\mathrm{V}$ films placed in air for 1 month, and the oxide layers grown on different $\mathrm{V}$ films have different compositions. The composition of natural oxidation layers can reflect the oxidation resistance of the $\mathrm{V}$ films. During the oxidation of vanadium, the $\mathrm{O}^{2-}$ needs to grasp most electrons from metallic $\mathrm{V}$ to form vanadium oxides with the highest valance, requiring more energy compared with other valences. In other words, the less $\mathrm{V}^{5+}$ appeared in the oxide layers, the stronger the oxidation resistance of $\mathrm{V}$ films in the surrounding atmosphere. In this paper, we classified $\mathrm{V}^{2+}, \mathrm{V}^{3+}$, and $\mathrm{V}^{4+}$ as low-valence particles and $\mathrm{V}^{5+}$ as high-valence particles. On the XPS spectrum, the number of each kind of particle can be represented by the area of its corresponding peak. The area ratio $(r)$ of the peaks of low valence $\mathrm{V}^{2+}, \mathrm{V}^{3+}$, and $\mathrm{V}^{4+}$ to the highest valence $\mathrm{V}^{5+}\left[r=\left(\mathrm{SV}^{2+}+\mathrm{SV}^{3+}+\mathrm{SV}^{4+}\right) / \mathrm{SV}^{5+}\right]\left(\mathrm{SV}^{2+}, \mathrm{SV}^{3+}, \mathrm{SV}^{4+}\right.$, and $\mathrm{SV}^{5+}$ represent the areas of the peaks of $\mathrm{V}^{2+}, \mathrm{V}^{3+}, \mathrm{V}^{4+}$, and $\mathrm{V}^{5+}$, respectively.) were calculated to indicate the oxidation resistance of the $\mathrm{V}$ films prepared at different parameters in Figures 13 and 14 . The larger the value of $r$, the stronger the oxidation resistance of the film.
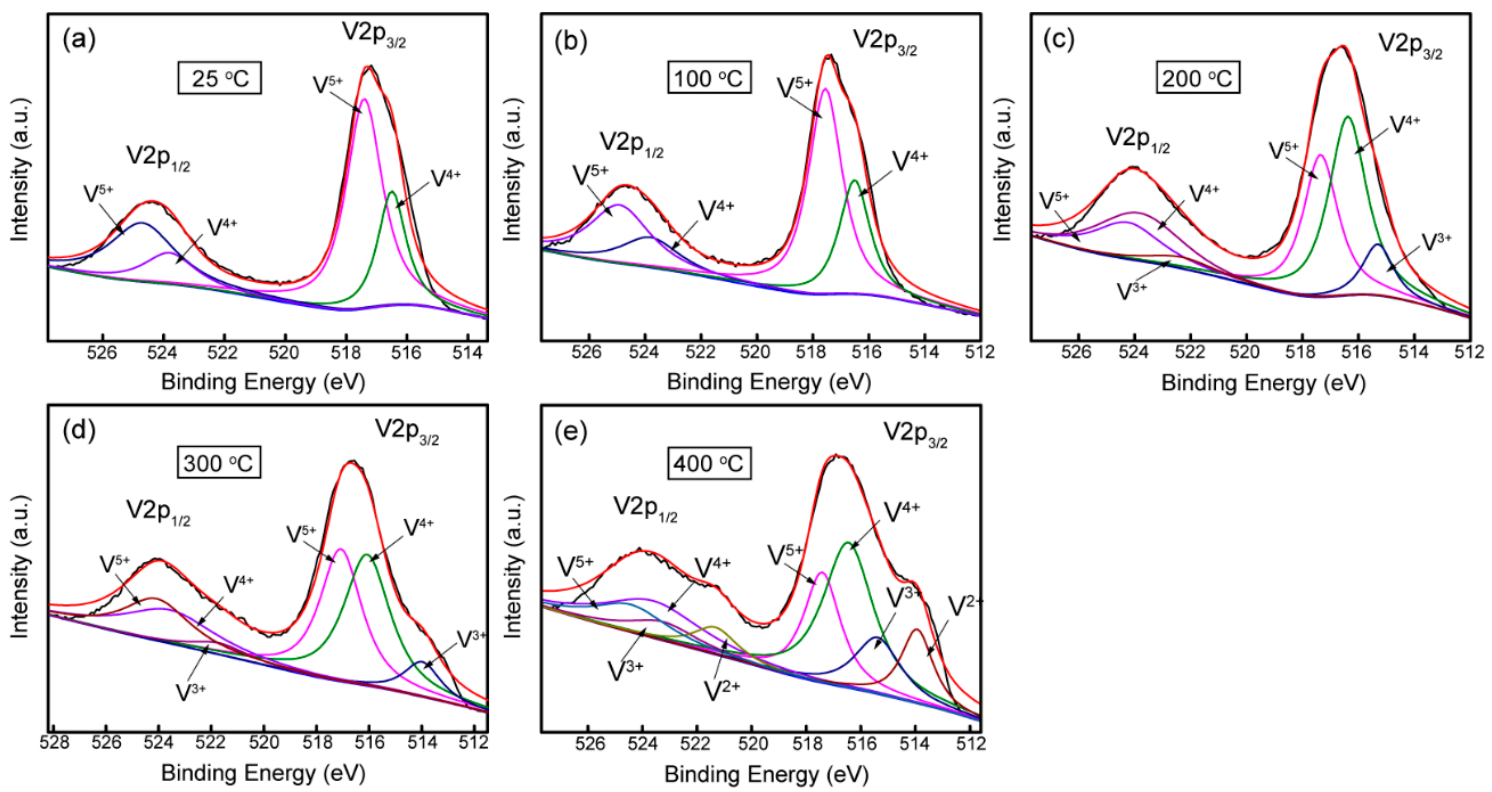

Figure 11. XPS spectra of V films deposited on Si (100) at $D_{\mathrm{t}-\mathrm{s}}=60 \mathrm{~mm}, \mathrm{~T}_{\mathrm{s}}=(\mathbf{a}) 25^{\circ} \mathrm{C},(\mathbf{b}) 100{ }^{\circ} \mathrm{C}$, (c) $200{ }^{\circ} \mathrm{C}$, (d) $300{ }^{\circ} \mathrm{C}$, and (e) $400{ }^{\circ} \mathrm{C}$. 

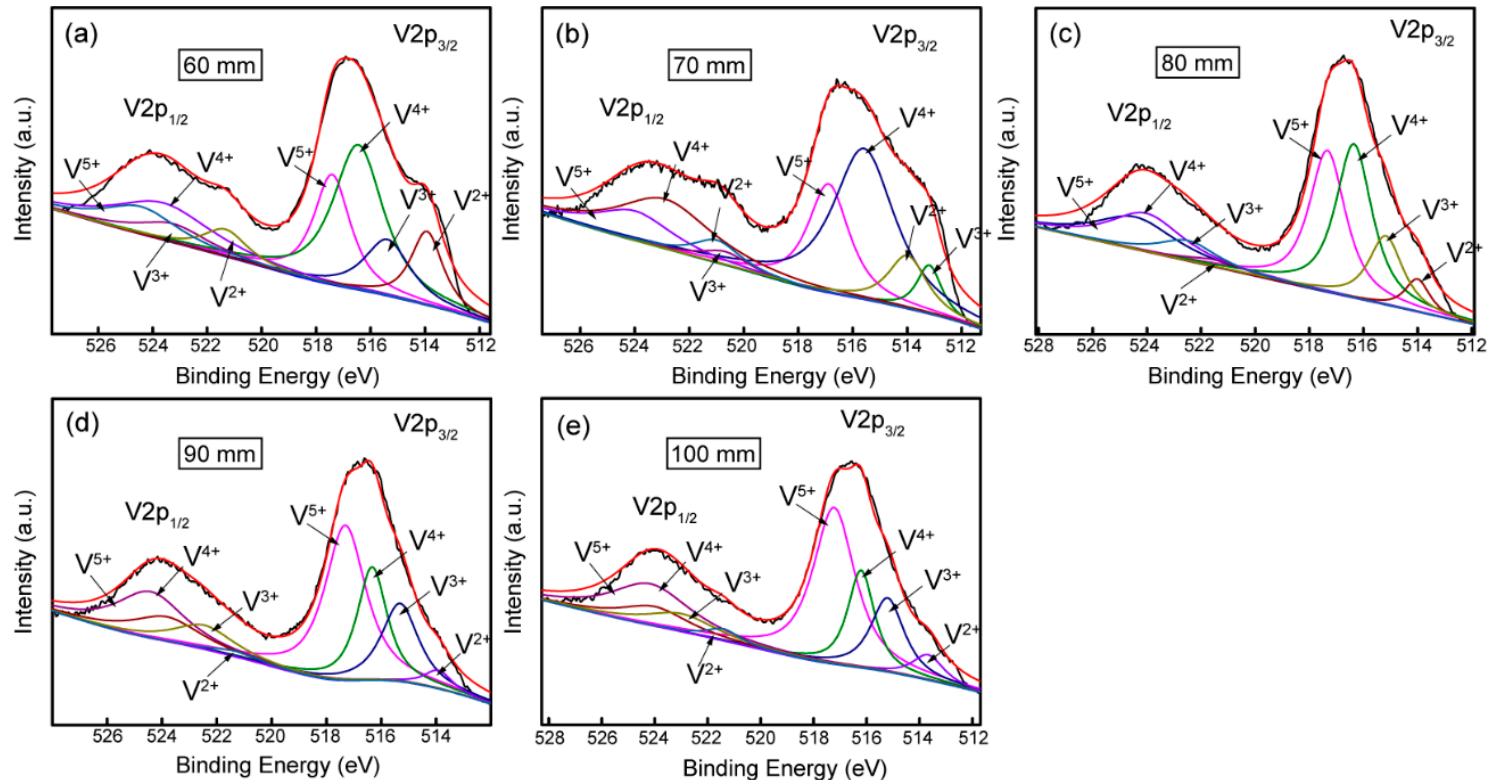

Figure 12. XPS spectra of V films deposited on Si (100) at $T_{\mathrm{s}}=400{ }^{\circ} \mathrm{C}, D_{\mathrm{t}-\mathrm{s}}=(\mathbf{a}) 60 \mathrm{~mm},(\mathbf{b}) 70 \mathrm{~mm}$, (c) $80 \mathrm{~mm}$, (d) $90 \mathrm{~mm}$, and (e) $100 \mathrm{~mm}$.

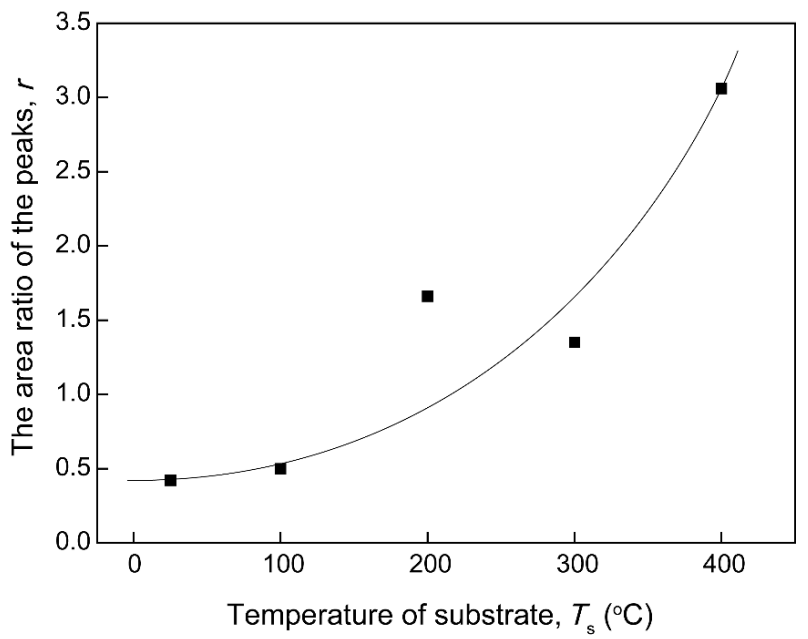

Figure 13. Effects of substrate temperatures $\left(T_{\mathrm{s}}\right)$ on the area ratio $(r)$ of the peaks of $\mathrm{V}$ films on $\mathrm{Si}(100)$.

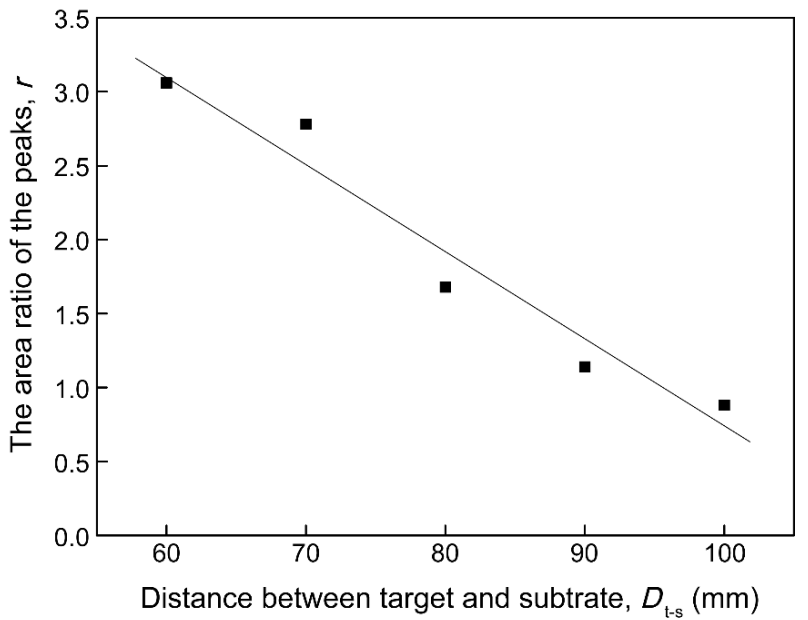

Figure 14. Effects of target-substrate distances $\left(D_{\mathrm{t}-\mathrm{s}}\right)$ on the area ratio $(r)$ of the peaks of $\mathrm{V}$ films on $\mathrm{Si}(100)$. 
Figure 11 shows the composition of the oxide layers of $\mathrm{V}$ films prepared at $D_{\mathrm{t}-\mathrm{s}}=60 \mathrm{~mm}$ with different $T_{\mathrm{s}}$. At $T_{\mathrm{s}}$ of 25 and $100{ }^{\circ} \mathrm{C}$, the XPS spectra shows the presence of $\mathrm{V}^{4+}$ and $\mathrm{V}^{5+}$ valances. When $T_{\mathrm{s}}$ increases to $200{ }^{\circ} \mathrm{C}$ and $300{ }^{\circ} \mathrm{C}, \mathrm{V}^{3+}$ appears on the surface of $\mathrm{V}$ films. At $T_{\mathrm{s}}$ of $400{ }^{\circ} \mathrm{C}$, there are not only $\mathrm{V}^{3+}, \mathrm{V}^{4+}, \mathrm{V}^{5+}$ valances, but also $\mathrm{V}^{2+}$ in the oxide layer. We found that an obvious shift of $\mathrm{V} 2 \mathrm{p}_{2 / 3}$ peaks toward the low binding energy was induced by increasing $T_{\mathrm{S}}$. As can be seen from the curve in Figure 12, the area ratio $(r)$ of the peaks increases with an increase in $T_{\mathrm{s}}$. This result indicates that the oxidation resistance of $\mathrm{V}$ film gradually becomes stronger as $T_{\mathrm{s}}$ increases. This increased oxidation resistance of $\mathrm{V}$ films may be related to the smaller specific surface area of the large particles on the film surface at higher $T_{\mathrm{S}}$ (Figure 2). In addition, the oxidation resistance of $\mathrm{V}$ films also should be due to the good crystallinity of films with larger grains obtained at a high $T_{\mathrm{S}}$ [24], confirmed by the results of XRD (Figure 1). The diffusion of oxygen is weakened due to an increase in grain size and a decrease in interfacial area as the crystallinity increases.

XPS spectra of V 2p and the area ratio $(r)$ of the peaks of $V$ films deposited at $T_{\mathrm{s}}=400{ }^{\circ} \mathrm{C}$ with different $D_{\mathrm{t}-\mathrm{s}}$ are shown in Figures 13 and 14, respectively. It can be seen from Figures 13 and 14 that the relative quantity of $\mathrm{V}^{5+}$ in the highest valence state increases as $D_{\mathrm{t}-\mathrm{s}}$ increases, and $\mathrm{V}^{3+}$ and $\mathrm{V}^{2+}$ in the low valence state gradually decreases. This result indicates that as $D_{t-s}$ increases, the oxidation resistance of the $\mathrm{V}$ film gradually weakens. The oxidation resistance should be due to the reduced crystallinity and preferred orientation of $\mathrm{V}$ films with smaller grains obtained at larger $D_{\mathrm{t}-\mathrm{s}}$.

\section{Conclusions}

Structure and surface morphology have been studied on V films grown on Si substrates with various $T_{\mathrm{s}}$ and $D_{\mathrm{t}-\mathrm{s}}$. We obtained films with good crystallinity and preferred $<111>$-orientation at higher $T_{\mathrm{s}}$ and lower $D_{\mathrm{t}-\mathrm{s}}$. The shape of the surface particles gradually become more regular and the size of the particles decreased with increasing $T_{\mathrm{s}}$ and decreasing $D_{\mathrm{t}-\mathrm{s}}$. The morphology of the $\mathrm{V}$ films prepared at $T_{\mathrm{s}}=400{ }^{\circ} \mathrm{C}$ and $D_{\mathrm{t}-\mathrm{s}}=60 \mathrm{~mm}$ presents a triangular pyramid shape, with typical characteristics of preferred $<111>$-orientation. In addition, we found that films with better crystallinity and larger surface particles are less susceptible to oxidation in air.

Author Contributions: R.T. and S.Z. conceived and designed the experiments; T.W. and Z.Z. performed the experiments; S.Z., T.W., and Z.Z. analyzed the data; J.L., Q.S., C.W., G.L. and L.Z. contributed reagents/materials/analysis tools; S.Z. and T.W. wrote the paper.

Funding: This research was funded by the Science Challenge Project (No.TZ2016001), the National Natural Science Foundation of China (Nos. 11602251, 51372188, 51861145306 and 51872212) and by the 111 Project (B13035). This research was also supported by the International Science \& Technology Cooperation Program of China (2014DFA53090), the Natural Science Foundation of Hubei Province, China (2016CFA006), the Fundamental Research Funds for the Central Universities (WUT: 2017YB004, 2018III016), and the State Key Laboratory of Advanced Technology for Materials Synthesis and Processing (WUT, Grant No. 2019-KF-12).

Acknowledgments: This work was supported by the Science Challenge Project (No.TZ2016001), the National Natural Science Foundation of China (Nos. 11602251, 51372188, 51861145306 and 51872212) and by the 111 Project (B13035). This research was also supported by the International Science \& Technology Cooperation Program of China (2014DFA53090), the Natural Science Foundation of Hubei Province, China (2016CFA006), the Fundamental Research Funds for the Central Universities (WUT: 2017YB004, 2018III016), and the State Key Laboratory of Advanced Technology for Materials Synthesis and Processing (WUT, Grant No. 2019-KF-12).

Conflicts of Interest: There are no conflict to declare.

\section{References}

1. Mamun, M.A.; Zhang, K.; Baumgart, H.; Elmustafa, A.A. Evaluation of the nanomechanical properties of vanadium and native oxide vanadium thin films prepared by RF magnetron sputtering. Appl. Surf. Sci. 2015, 359, 30-35. [CrossRef]

2. Chunwei, L. Study on Vanadium Films Deposited on Concave Object by Conventional Direct Current and High Power Pulsed Magnetron Sputtering. Rare Met. Mater. Eng. 2013, 42, 2437-2441. [CrossRef] 
3. Aramesh, M.; Fox, K.; Lau, D.W.M.; Fang, J.; Ostrikov, K.; Prawer, S.; Cervenka, J. Multifunctional three-dimensional nanodiamond-nanoporous alumina nanoarchitectures. Carbon 2014, 75, 452-464. [CrossRef]

4. Aramesh, M.; Djalalian-Assl, A.; Yajadda, M.M.A.; Prawer, S.; Ostrikov, K. Thin Nanoporous Metal-InsulatorMetal Membranes. ACS Appl. Mater. Interfaces 2016, 8, 4292-4297. [CrossRef] [PubMed]

5. Yoshinaga, H.; Toma, K.; Abe, K.; Morozumi, S. The portevin-le chatelier effect in vanadium. Philos. Mag. 1971, 23, 1387-1403. [CrossRef]

6. Hohenwarter, A.; Wurster, S. Deformation and fracture characteristics of ultrafine-grained vanadium. Mater. Sci. Eng. A 2016, 650, 492-496. [CrossRef]

7. Aksenov, V.K.; Chernyak, N.A.; Volchok, O.I.; Mats, A.V.; Starodubov, Y.D. Superconducting properties and structure of vanadium after cryogenic deformation. Low Temp. Phys. 1998, 24, 201-204. [CrossRef]

8. Yukawa, H.; Yamashita, D.; Ito, S.; Morinaga, M.; Yamaguchi, S. Compositional dependence of hydriding properties of vanadium alloys at low hydrogen pressures. J. Alloy. Compd. 2003, 356-357, 45-49. [CrossRef]

9. Li, C.W.; Tian, X.B.; Liu, T.W.; Qin, J.W.; Gong, C.Z. Microstructure and corrosion resistance of vanadium films deposited at different target-substrate distance by HPPMS. Rare Met. 2014, 33, 587-593. [CrossRef]

10. Wei, Q.; Jiao, T.; Ramesh, K.T.; Ma, E. Nano-structured vanadium: Processing and mechanical properties under quasi-static and dynamic compression. Scr. Mater. 2004, 50, 359-364. [CrossRef]

11. Binns, C.; Derbyshire, H.S.; Bayliss, S.C.; Norris, C. Appearance of surface magnetic moments on vanadium thin films and sensitivity to contamination. Phys. Rev. B 1992, 45, 460-463. [CrossRef]

12. Martin, M.L.; Pundt, A.; Kirchheim, R. Hydrogen-induced accelerated grain growth in vanadium. Acta Mater. 2018, 155, 262-267. [CrossRef]

13. Mogyorósi, P.; Szörényi, T.; Bali, K.; Tóth, Z.; Hevesi, I. Pulsed laser ablative deposition of thin metal films. Appl. Surf. Sci. 1989, 36, 157-163. [CrossRef]

14. Pedrosa, P.; Martin, N.; Salut, R.; Yazdi, M.A.P.; Billard, A. Controlled thermal oxidation of nanostructured vanadium thin films. Mater. Lett. 2016, 174, 162-166. [CrossRef]

15. Liang, S.; Mei, Z.X.; Du, X.L. Modulation of electrical and optical properties of gallium-doped ZnO films by radio frequency magnetron sputtering. Chin. Phys. B 2012, 21, 067306. [CrossRef]

16. Wang, X.C.; Yin, M.Y.; Mi, W.B. Grain boundary magnetism and conductivity in polycrystalline Ti1-xMnxN films by reactive sputtering. J. Alloy. Compd. 2013, 574, 539-545. [CrossRef]

17. Yang, K.; Jiang, J.Q.; Gu, M.Y. Effects of nitrogen partial pressure on microstructure, morphology and N/Ti ratio of TiN films deposited by reactive magnetron sputtering. Mater. Sci. Technol. 2007, 23, 958-962. [CrossRef]

18. Zhang, S.; Xu, Q.; Tu, R.; Goto, T.; Zhang, L. Growth mechanism and defects of <111>-oriented $\beta$-SiC films deposited by laser chemical vapor deposition. J. Am. Ceram. Soc. 2015, 98, 236-241. [CrossRef]

19. Weng, M.H.; Pan, C.T.; Yang, R.Y.; Huang, C.C. Structure, optical and electrical properties of ZnO thin films on the flexible substrate by cathodic vacuum arc technology with different arc currents. Ceram. Int. 2011, 37, 3077-3082. [CrossRef]

20. Xu, X.L.; Lau, S.P.; Chen, J.S.; Sun, Z.; Tay, B.K.; Chai, J.W. Dependence of electrical and optical properties of ZnO films on substrate temperature. Mater. Sci. Semicond. Process. 2001, 4, 617-620. [CrossRef]

21. Natarajan, G.; Daniels, S.; Cameron, D.C.; McNally, P.J. Influence of target to substrate distance on the sputtered $\mathrm{CuCl}$ film properties. Thin Solid Film 2008, 516, 5531-5535. [CrossRef]

22. Radmilovic, V.; Dahmen, U.; Gao, D.; Stoldt, C.R.; Carraro, C.; Maboudian, R. Formation of $<111>$ fiber texture in $\beta$-SiC films deposited on Si(100) substrates. Diam. Relat. Mater. 2007, 16, 74-80. [CrossRef]

23. Hryha, E.; Rutqvist, E.; Nyborg, L. Stoichiometric vanadium oxides studied by XPS. Surf. Interface Anal. 2012, 44, 1022-1025. [CrossRef]

24. Park, M.H.; Kim, S.H. Temperature coefficient of resistivity of TiAlN films deposited by radio frequency magnetron sputtering. Trans. Nonferrous Met. Soc. China 2013, 23, 433-438. [CrossRef]

(C) 2019 by the authors. Licensee MDPI, Basel, Switzerland. This article is an open access article distributed under the terms and conditions of the Creative Commons Attribution (CC BY) license (http:/ / creativecommons.org/licenses/by/4.0/). 